\title{
Sınıf Öğretmenleri ve Okul Yöneticilerinin İlkokul Programlarının Güncellenmesine İlişkin Görüşlerinin İncelenmesi
}

Taner Altun ${ }^{* 1}$, Aybüke Baştürk ${ }^{2}$ ve Ahmet Gülay ${ }^{3}$

Öz

$\mathrm{Bu}$ araştırmada, sınıf öğretmenlerinin ve okul yöneticilerinin ilkokul programlarının güncellenmesine ilişkin görüşlerinin belirlenmesi amaçlanmıştır. Araştırma nitel araştırma yaklaşımı çerçevesinde tasarlanmış olup, araştırmada durum çalışması yöntemi işe koşulmuştur. Araştırmanın çalışma grubunu, amaçlı örnekleme yöntemiyle belirlenen 10 sinıf öğretmeni ve 5 okul yöneticisi oluşturmuştur. Araştırmanın verileri, yarı yapılandırılmış görüşme tekniği ile toplanmıştır. Elde edilen veriler içerik analizine tabi tutulmuştur. Araştırmanın bulguları; programların değiştirilme nedenlerine ilişkin görüşler, programların güncellenme sürecine ilişkin eleştiriler, öğretim programlarının tanıtımlarına ilişkin görüşler, öğretim programlarının geliştirilmesine yönelik öneriler, programların değişme sıklığına ilişsin görüşler ve 2017 öğretim programına ilişkin görüşler temaları altında değerlendirilmiştir. Araştırma sonucunda hem sınıf öğretmenlerinin hem de okul yöneticilerinin öğretim programlarının sıklıkla değiştiği ve bu durumun çağın ihtiyaçlarını yakalama çabasından kaynaklandığı görüşünde oldukları belirlenmiştir. Araştırma sonunda öğretim programlarının daha az sıklıkta, bir öncekinin çıktılarının değerlendirilerek ve bütün eğitim paydaşlarının görüşlerinin alınarak güncellenmesi önerilmiştir.

\author{
Anahtar Sözcükler \\ Öğretim programları \\ Temel eğitim \\ Sınıf öğretmeni \\ Okul yöneticisi \\ Makale Hakkında \\ Gönderim Tarihi \\ 23 Eylül 2018 \\ Kabul Tarihi \\ 11 Ocak 2019 \\ Makale Türü \\ Araștırma Makalesi
}

DOI: $10.12984 /$ egeefd. 462958

\section{Examining the Views of Primary School Teachers and School Administrators on the Updating of Primary School Curriculum}

\section{Abstract}

The aim of this study is to determine the views of classroom teachers and school administrators on the updating of primary school curriculum. This qualitative research employs the case study method. The study group of the research was composed of 10 classroom teachers and 5 school administrators selected by convenience sampling. The study data were gathered by semi-structured interview technique. The collected data were subjected to content analysis. The findings are presented under the following themes: views on the reasons for changing the curriculum, criticisms towards updating the curriculum, views on the familiarisation of the curriculum, suggestions for developing the curricula, views on the frequency of changing the curricula, and views related to the 2017 curriculum. The research findings revealed that both the class teachers and school administrators believed the curriculum were frequently changed, and that this situation arose from efforts to meet the current needs. At the end of the study, it is suggested that curricula should be updated less frequently, and that they should be updated by considering the outputs of the previous ones and by obtaining the opinions of all stakeholders in education.
Keywords

Curriculum Primary education Classroom teacher School principal

Article Info

Received

September, 23, 2018

Accepted

January 11, 2019

Article Type

Research Paper

Atıf: Altun, T., Baştürk, A. ve Gülay, A. (2019). Sınıf öğretmenleri ve okul yöneticilerinin ilkokul programlarının güncellenmesine ilişkin görüşlerinin incelenmesi. Ege Eğitim Dergisi, 20(1), 209-222. doi:10.12984/egeefd.462958

\footnotetext{
* Sorumlu Yazar/Corresponding Author

${ }^{1}$ (1) Trabzon Üniversitesi, Fatih Eğitim Fakültesi, Temel Eğitim Bölümü, Türkiye, taltun@trabzon.edu.tr

2 당 Trabzon Üniversitesi, Fatih Eğitim Fakültesi, Temel Eğitim Bölümü, Türkiye, a.ucansoy@ @mail.com

3 (ㄷ) Trabzon Üniversitesi, Fatih Eğitim Fakültesi, Temel Eğitim Bölümü, Türkiye, ahmetgulay61@ @otmail.com
} 


\section{Extended Abstract}

\section{Introduction}

The developments in science and technology necessitate changes in the structure and expectations of society, various concerns and needs of individuals are subject to these changes, raising students' progress levels, and creating and amending standards in education (Çubukçu, 2008; Ekiz, 2012). In other words, the needs of society continually call for the systematic development of curriculum (Kahramanoğlu, 2017).

Curriculum development is a comprehensive and continuous process (Demirel, 2008). Erden (1998) defined this extensive process as "the design, implementation, evaluation, and consequently, the reorganisation of curriculum". In this respect, curricula must not only be developed scientifically, systematically and in a quality way, they must also be evaluated continually and actively (Özdemir, 2009). However, this evaluation must be carried out in accordance with the views given by teachers following implementation (Baş, 2016). Otherwise, the current curriculum may be unsuccessfully announced and every new curriculum that is developed may be presented as a comprehensive education reform (Şahin, 2009).

Criticisms are made of curriculum development efforts in Turkey with regard to disconnection and lack of communication between operating units, inadequate needs assessment and pilot studies, and unsystematic realisation of commission efforts (Altun \& Şahin, 2009). The curricula developed in this way without forming the necessary bases in education can make the work of teachers, who are the implementers, more complicated and onerous (Lau, 2001) and can sometimes create an atmosphere of chaos (Altun \& Sahin, 2009). The curriculum development requires team work and participation (Varış, 1996). In this respect, more attention needs to be paid to the views of teachers and school administrators with regard to the curriculum.

The aim of this study is to examine the views of class teachers and school administrators on the updating of primary school curriculum. In the study, answers are sought to the following questions:

1. What are the views of class teachers and school regarding the frequency of changing the curriculum in Turkey?

2. What are the opinions of class teachers and school administrators regarding the process for developing the curriculum in Turkey?

3. What are the suggestions of class teachers and school administrators for updating the primary school curriculum in Turkey?

4. What are the views of class teachers and school administrators regarding the 2017 primary school curriculum?

\section{Method}

In this study, qualitative research design was used in order to investigate the viewpoints of participants in-depth (Büyüköztürk, Çakmak, Akgün, Karadeniz \& Demirel, 2010; Ekiz, 2015). To obtain in-depth views of the classroom teachers and school administrators related to updates of the curriculum in the study, and to understand the existing one in an unprejudiced way, the case study method was employed (Baxter \& Jack, 2008; Ekiz, 2015; Johnson \& Christensen, 2014; Stake, 1995; Wellington, 2000; Yin, 1994).

For selecting the classroom teachers who made up the study group, one of the purposeful sampling methods, the criterion sampling method, was chosen. The criterion sampling method gives researchers the opportunity to define specific criteria related to the subject in the data collection process (Şimşek \& Yıldırım, 2011). In this respect, with the aim of drawing a clearer picture of the research context, as the number of updates carried out in the curriculum has been particularly high since 2005 , when selecting the class teachers, researchers ensured that the participants had at least 12 years of experience. For selecting the school administrators who made up the other participant group, the convenience sampling method was chosen. In this respect, the school administrators were selected by the fact that they were both easy to reach and willing to participate voluntarily in the study.

The research data were gathered by means of semi-structured interviews prepared by the researchers. The interviews were recorded with recording devices or notes taken by the researchers, depending on the preferences and permission of the participants. These recorded data were transcribed and subjected to content analysis by the researchers. By means of the content analysis, codes and categories were created by gathering similar meanings together (Büyüköztürk et al., 2010). Finally, the data were presented in table form. The tables were supported by giving sample quotes from the views of the class teachers and school administrators. 


\section{Findings}

The research findings revealed that the class teachers and school administrators considered that especially contemporary needs and meeting these needs were effective for updating the curriculum. It was seen that some teachers in the study, however, considered that the curriculum were changed by the ideological decisions of the authorities.

In the study it was determined that the great majority of school administrators and class teachers believed that they were not adequately informed about updates to the curriculum, that their opinions were not sufficiently sought, and that familiarisation was not adequately carried out.

The research findings revealed that both the class teachers and the school administrators believed that the curriculum was updated frequently and without taking the outputs of the current programme into consideration.

In the study, the class teachers and school administrators stated that they wanted curriculum to be aimed at differences in students' levels and to be in the form of a general framework. On the other hand, some participants indicated that all details should be included in the curriculum. The different views of the teachers on this subject may be due to differences in attitude towards the curriculum and their implementation and content enrichment. Finally, it was determined that the participants considered the 2017 teaching programme to be rather simple and that the school administrators' views differed with regard to the ability of this curriculum to meet the needs and expectations of the nation.

\section{Discussion and Conclusion}

Updating a curriculum is a complex process as there are various factors which effect his process. Contemporary needs play a crucial role in developing the curriculum. Ideological views of the policy makers are one of the effective elements in this process. Examination of the literature reveals that some researchers (Ersoy, 2007; Kahramanoğlu, 2017; Şahin, 2009; Yüksel, 1998) were of a similar opinion and that they criticised this centralist understanding.

Informing associated stakeholders about the change in the curriculum is important in terms of disseminating and implementing it. In this study it was revealed that introducing the changes in curriculum to teachers and school managers were not adequately carried out. In a study conducted by Taşdemir et al. (2018), it was also stated that teachers were not adequately informed about new curricula and that they felt the need for in-service training. The teachers' views related to updating of previous curriculum were of a similar nature. According to the teachers, they were given short seminars regarding the 2005 curriculum which was directed towards theory rather than practice, and sufficient familiarisation was not provided (Altun \& Şahin, 2009; Bukova Güzel \& Alkan, 2005; Güven, 2008; Hazır Bıkmaz, 2006; Karacaoğlu \& Acar, 2010).

In the current study it was concluded that frequent changes in the curriculum effects the quality of teaching practice in schools. Similar to this view, Gelen \& Beyazit (2007) reported that curriculum remained in force for the short term only. Indeed, especially in the past few years, the existing programmes have been applied for short periods and have been updated without adequate assessment.

Based on the findings of the study, following recommendations were made:

- More detailed explanations related to the reasons for updating the curriculum should be given to stakeholders in education and more active participation of these stakeholders at every stage of the updating process should be ensured.

- The curriculum should be updated based on program evaluations and having their output assessed over longer periods.

- The primary school curriculum may be prepared in the form of a general framework in which teachers are given the ability to ensure flexibility in line with the environments where they are employed and with the characteristics of the students. 


\section{Giriş}

Sürekli değişen ve gelişen dünyamızda toplumun ve çağın ihtiyaçlarını karşılamada eğitimin önemi yadsınamaz düzeydedir. Bilim ve teknolojinin gelişmesi, toplumun yapısının ve beklentilerinin değişmesi, bu değişime bağlı olarak bireylerin ilgi ve ihtiyaçlarının farklılaşması, öğrencilerin gelişim seviyelerinin yükselmesi eğitimde standartlar oluşturmayı ve değişikliklere gitmeyi gerektirmektedir (Çubukçu, 2008; Ekiz, 2012). Yani toplumun ihtiyaçları, öğretim programlarının sistematik bir şekilde sürekli olarak geliştirilmesine yol açmaktadır (Kahramanoğlu, 2017). Bir başka deyişle, toplumun yaşam niteliğini geliştirmek, toplumsal, kültürel değerleri korumak ve sürdürülebilir kalkınmayı sağlamak için öğretim programları güncellenmek, yenilenmek ve değiştirilmek zorundadır (Özdemir, 2009; Tutkun ve Aksoyalp, 2010). Bu bakımdan ilgili kurumlardan ve yetkili kişilerden öğretim programlarını mevcut toplumsal yapıya hitap edecek şekilde oluşturmaları beklenmektedir. Çünkü program geliştirmenin en temel amacı, öğrencilerin, okul ile çevresindeki hayatın ve toplumun geliştirilmesidir (Demirel, 2008). Toplumun ve ülkenin geliştirilmesi ise ancak öğretim programlarının geleceği öngörebilecek ve onun koşullarını geliştirebilecek bireyler yetiştirebilmesine bağlıdır (Gömleksiz, 2007; Pintó, $2005 ;$ ). Bu durum öğretim anlayışında, ders içeriklerinde ve program oluşturmada yeniliklerin olmasını kaçınılmaz hale getirmektedir (Altun ve Şahin, 2009). Nitekim daha etkilisini ve kalitelisini geliştirmek için öğretim programlarında yeniliklere gidilmesi sürekli olarak devam etmektedir.

Program geliştirme, eğitim süreciyle ilgili bütün koşulların, bireylerin, ders kitapları ve araçların sürekli geliştirilmesidir (Varış, 1996). Program geliştirme, kapsamlı ve sürekli devam eden bir süreçtir (Demirel, 2008). Erden (1998) bu kapsamlı süreci "öğretim programlarının tasarlanması, uygulanması, değerlendirilmesi ve bunun sonucunda yeniden düzenlenmesi” olarak tanımlamıştır. Bu bakımdan öğretim programları bilimsel, sistematik, koordineli ve nitelikli bir şekilde geliştirilmelerinin yanında sürekli ve aktif olarak değerlendirilmelidirler (Özdemir, 2009). Böylelikle öğretim programlarının gelişmesinde veya yenilenmesinde süreklilik sağlanmaktadır. Ayrıca uygulanan öğretim programlarının etkililiği hakkında karara varılmaktadır (Taşdemir ve diğ., 2018). Çünkü yürürlükte olan bir öğretim programını güncellemek için öncelikle ne derece etkili olduğunun incelenmesi ve değerlendirilmesi gerekir (Varış, 1996). Bu değerlendirme öğretmenlerin uygulamalar sonucundaki görüşlerine göre gerçekleştirilmelidir (Baş, 2016). Aksi takdirde geliştirilen her yeni öğretim programı kapsamlı bir eğitim reformu olarak sunulmaktadır (Şahin, 2009). Bunun sonucunda eğitimdeki sorunların temel sebebinin mevcut öğretim programı olduğu ve bunun ancak yeniden program geliştirmeyle çözüleceği algısı oluşturulabilmektedir. Yani her program geliştirme sürecinde, mevcut programlar başarısız olarak ilan edilebilmektedir. Oysa ki bu durumun temel sebebi, öğretim programlarının geliştirilmesinin ve uygulanmasının kısa süreli olmasıdır (Gelen ve Beyazıt, 2007). Bu bakımdan öğretim programlarının uzun süreli uygulamalar sonucunda elde edilen çıktıların değerlendirilmesi sonucunda güncellenmeleri gerekmektedir.

Her ülkede olduğu gibi Türkiye'de de çağın gereksinimlerini yakalamak amacıyla öğretim programı geliştirme ve güncelleme çalışmaları gerçekleştirilmektedir. Bilindiği üzere ülkemizde ilk program geliştirme çalışması eğitim kuramcısı John Dewey'in katkılarıyla 1924 yılında yapılmıştır. Bu program sırasıyla 1926, 1936, 1939 ve 1948 yıllarında güncelleştirilerek iyileştirilmeye çalışılmıştır (Akınoğlu, 2005). 1960’lı yıllara gelince köklü değişiklikler yapılarak geliştirilen program 1968 yılından itibaren uygulanmaya başlanmıştır. $\mathrm{Bu}$ mevcut program anlayışı üzerinde 1980 ve 1990'll yıllarda da birtakım değişiklikler gerçekleştirilmiştir. 2005 yılında ise, öğretim programlarında öğrenci merkezli yaklaşım benimsenerek ve özellikle yapılandırmacı kuram ile çoklu zekâ kuramı esas alınarak köklü değişikliğe gidilmiştir. Bu programda 2009 ve 2013 gibi yıllarda özellikle dersler bazında bazı değişiklikler gerçekleştirilmiştir. İlkokul öğretim programlarında son olarak 2015 yılında ciddi değişiklikler yapılmıştır. Programda değer ve değerler eğitimine vurgu yapılmış ve bu kavramlar programın odak noktasına konulmuştur. Ayrıca 2015 öğretim programında uygulanmakta olan programa göre sadeleştirilmeye gidilmiş ve derslerdeki kazanım sayıları önemli derecede azaltılmıştır. Hayat Bilgisi dersinde üç temanın yerine altı ünitenin yer alması ve ilk okuma yazma sürecinde harflerin öğretim sırasının değişmesi programın getirdiği dikkat çekici yeniliklerdendir. Bu programa ilişkin ise 2016, 2017 ve 2018 yıllarında güncellemeler gerçekleştirilmiştir. Özellikle 2017 yılında ilkokul öğretim programında bitişik eğik el yazısından vazgeçilmesi gibi köklü değişimler olmuştur. Bu öğretim programı 2017-2018 eğitim-öğretim yılı itibariyle uygulamaya konulmuştur. Bu programda 2018 yılında da birtakım değişiklikler öngörülmüsş, gerçekleştirilmiş ve programın 2018-2019 eğitim-öğretim yılından itibaren uygulanmaya başlanması kararlaştırılmıştır. Özetle ülkemizdeki öğretim programları geliştirme sürecinin tarihçesine bakıldığında önceki yıllarda öğretim programlarının uzun süreli olarak uygulandığı fakat 2000'li yıllardan sonra kısa süreli aralıklarla değiştirildiği veya güncellendiği görülmektedir.

Ülkemizdeki program geliştirme çalışmalarına, yürüten birimler arasında kopukluk ve iletişimsizlik olması, ihtiyaç tespitlerinin ve pilot uygulamaların yeterince yapılmaması, komisyon çalışmalarının sistemsiz bir şekilde gerçekleşmesi noktalarında eleştiriler getirilmektedir (Altun ve Şahin, 2009). Oysaki program geliştirmenin masa başında bazı konuların çıkarılıp onların yerine yeni konuların eklenmesi şeklinde yapılmaması gerekliliği Gelen ve Beyazıt (2007)'ın çalışmalarında da üzerinde durulan bir konudur. Bu şekilde eğitimde gerekli temeller 
oluşturulmadan bireylere bağlı olarak geliştirilen öğretim programları farklı bölgelerdeki öğrencilerin ihtiyacını ve beklentisini yeterince karşılayamamakta (Yüksel, 1998), uygulayıcısı olan öğretmenlerin işlerini daha karmaşık ve ağır hale getirebilmekte (Lau, 2001) ve bazen kaos ortamı oluşturabilmektedir (Altun ve Şahin, 2009). Çünkü program geliştirme, ekip çalışması ve katılımı gerektirir (Varış, 1996). Bu ekibin en önemli üyesi ise, programın uygulanmasında daha fazla sorumluluğu olan öğretmenlerdir. Bu bağlamda öğretmenler, program geliştirme sürecinde daha fazla söz hakkına sahip olmalıdırlar. Bunun yanında öğretim programlarının daha sağlıklı bir şekilde yürütülebilmesi içi okul yöneticilerinin de programlara liderlik edebilmesi, ona ilişkin planlar yapabilmesi ve kararlar alabilmesi gerekir (Yar Yıldırım, 2018). Bu bakımdan öğretmenlerin ve okul yöneticilerinin öğretim programlarına ilişkin bilgilerinin ve düşüncelerinin ciddi önem taşıdığı ifade edilebilir.

Öğretim programları, öğretmenlerin bu yönde uyarımı ve isteğiyle geliştirilmelidir (Varış, 1996). Çünkü öğretmenlerin öğretim programlarına ilişskin görüş ve inançları (Tutkun ve Aksoyalp, 2010; Gömleksiz, 2007; Yıldırım, Kandemir, Çınar ve Durak, 2017) ve uygulamalardan edindikleri tecrübeler programların etkili ve başarılı bir şekilde geliştirilmesinde, uygulanmasında, yürütülmesinde ve değiştirilmesinde oldukça önemli bir role sahiptir (Yüksel, 1998). Yüksel'e göre, etkili ve başarılı bir öğretim programı geliş̧irmek için öğretmen, yönetici ve veli gibi eğitimin tüm paydaşlarının sürece katılımı sağlanmalıdır. Bu paydaşlar öğretim programlarının gelişiminde kritik roller oynayabilirler (Oliva ve Gordon, 2018). Bu bağlamda özellikle program geliştirmede en temel grup olan öğretmenlerin sürecin her aşamasında yer almaları gerekir (Doll, 1996; Karakuş ve Mengi Us, 2014; Oliva, 2009; Ornstein ve Hunkins, 2013). Fakat ülkemizde program geliştirme çalışmaları Millî Eğitim Bakanlı̆̆ı'nın kararıyla ve kontrolüyle merkeziyetçi bir şekilde gerçekleştirilmekte, eğitimin bütün paydaşlarının katılımı sağlanamamakta (Ersoy, 2007; Kahramanoğlu, 2017) ve okullara, öğretmenlere ve uzmanlara yeterince rol verilmemektedir (Akpınar, 2012). Nitekim öğretmenler kendi görüşlerinin alınmamasından dolayı programların doğru ve sağlıklı bir şekilde geliştirilmediğini ve değerlendirilmediğini düşünmektedirler (Karakuş ve Mengi Us, 2014).

İlgili alanyazın genel olarak değerlendirildiğinde ülkemizde öğretim programlarına ilişkin bazı çalışmalar olduğu görülmektedir. Bu araştırmaların bir bölümü 2005 öğretim programının incelenmesi (Bukova Güzel ve Alkan, 2005; Gelen ve Beyazıt, 2007; Hazır Bıkmaz, 2006), öğretmenlerin bu programa ilişkin görüşlerinin (Altun ve Şahin, 2009; Gömleksiz, 2007; Güven, 2008; Özpolat, Sezer, İşgör ve Sezer, 2007) ve karşılaştıkları sorunların (Karacaoğlu ve Acar, 2010) belirlenmesi üzerinedir. Çalışmaların diğer bir bölümü ise öğretim programlarını değerlendirmeye (Demirtaş, 2017; Karakuş ve Mengi Us, 2014; Kürüm Yapıcıŏlu, Atik Kara ve Sever, 2016; Özdemir, 2009) yöneliktir. Alanyazında öğretim programına ilişkin ilkokul düzeyinde dersler bazında araştırmalar (Aydın, 2017; Şahin, 2009; Taşdemir ve diğ., 2018; Yapıcı ve Demirdelen, 2007; Yıldırım ve diğ., 2017) da bulunmaktadır. Fakat eğitimin önemli paydaşlarından olan öğretmenlerin (Baş, 2016; Yüksel, 1998) ve okul yöneticilerinin (Yar Yıldırım, 2018) program geliştirme sürecine katılmalarına ilişkin çalışmalar ise çok sınırlıdır. Bu paydaşların birlikte yer aldığı tek bir araştırmaya rastlanılmıştır (Gökçe, 1993) ve bu araştırma da ortaöğretim düzeyindedir. Öğretim programlarına ilişkin öğretmenlerin ve okul yöneticilerinin görüşlerinin birlikte incelendiği ilkokul düzeyinde araştırmaya ise rastlanılamamışıı. Ayrıca öğretim programlarında 2015 yılından sonra yapılan güncellemelere yönelik çalışmalar (Aydın, 2017; Taşdemir ve diğ., 2018; Yıldırım ve diğ., 2017) da oldukça sınırlıdır. Bu yönüyle alan yazında bir boşluk olduğu ve bu araştırmanın bunu giderme çabası olduğu ifade edilebilir.

$\mathrm{Bu}$ araştırmada, sınıf öğretmenlerinin ve okul yöneticilerinin ilkokul programlarının güncellenmesine ilişkin görüşlerinin belirlenmesi amaçlanmıştır. Araştırmada katılımcı sınıf öğretmenleri ve okul yöneticilerinin ilkokul programlarının sık değişmesine, program geliştirme sürecine ilişkin görüş ve önerileri derinlemesine incelenmesi amaçlanmıştır.

İlgili alanyazın değerlendirildiğinde öğretim programlarına ilişkin görüşlerin incelendiği araştırmaların çoğunun çalışma grubunu öğretmenlerin oluşturduğu görülmektedir. Çalışma grubunda sınıf öğretmenlerinin yanında okul yöneticilerinin de yer alması bakımından bu araştırmanın zenginlik içerdiği ve önem teşkil ettiği ifade edilebilir. Ayrıca öğretim programlarının uygulayıcıları olan öğretmenlerin ve uygulanmasını sağlayan okul yöneticilerinin güncellemelere ilişkin görüşlerinin belirlenmesinin önemli olduğu belirtilebilir.

$\mathrm{Bu}$ araştırmada katılımcı sınıf öğretmenleri, ölçüt örnekleme yöntemiyle seçilmiştir. Bu bakımdan sınıf öğretmenlerinin en az 12 yıllık mesleki yaşantılarının bulunmasına dikkat edilmiştir. Çünkü Türkiye'de öğretim programları özellikle 2005 yılından itibaren sıklıkla güncellenmektedir. Böylece katılımcı sınıf öğretmenlerinin son yıllarda güncellenen bütün programlara ilişkin tecrübelerinin olması sağlanmıştır. Araştırma bu yönüyle ilgili alanyazın açısından önem arz edebilir. 
Yöntem

\section{Araştırmanın Deseni}

Araştırmada katılımcıların bakış açısına odaklanmak ve düşüncelerini derinlemesine incelemek amacıyla nitel araştırma deseni kullanılmıştır (Büyüköztürk ve diğ., 2010; Ekiz, 2015). Çalışmada nitel araştırma desenlerinden ise durum çalışması işe koşulmuştur. Bu yöntemde araştırmacı bir durum üzerine yoğunlaşarak ön yargısız bir şekilde var olanı anlamaya ve betimleyici sorular kullanarak derinlemesine bilgiler elde etmeyi amaçlar (Baxter ve Jack, 2008; Ekiz, 2015; Johnson ve Christensen, 2014; Stake, 1995; Wellington, 2000; Yin, 1994). Bu amaca yönelik olarak araştırmada durum çalışmasının işe koşulmasıyla sınıf öğretmenlerinin ve okul yöneticilerinin programların güncellenmesine ilişkin algılarının detaylı olarak incelenmesi amaçlanmıştır.

\section{Çalısma Grubu}

Çalışma grubunu oluşturan sınıf öğretmenlerinin belirlenmesinde amaçlı örneklem yöntemlerinden 'ölçüt örnekleme' yöntemi tercih edilmiştir. Ölçüt örnekleme yöntemi, araştırmacılara konuya ilişkin veri toplama sürecinde belirli ölçütler tanımlayabilme firsatı vermektedir (Şimşek ve Yıldırım, 2011). Bu bakımdan çalışmanın bağlamına ilişkin resmi daha iyi çizebilmek adına, özellikle 2005 yılından itibaren öğretim programlarında gerçekleştirilen güncellemelerin çok olmasından dolayı, sınıf öğretmenleri belirlenirken, katılımcıların en az 12 yıllık mesleki deneyime sahip olmalarına ve dikkat edilmiştir.

Çalışmanın bir diğer katılımcı grubunu oluşturan okul yöneticilerinin belirlenmesinde ise 'kolay ulaşılabilir örnekleme' yöntemi tercih edilmiştir. Bu bakımdan okul yöneticileri kolay ulaşılabilecek olmasının yanında çalışmaya katılmaya gönüllü, istekli olacak şekilde belirlenmişlerdir. Katılımcılara ilişkin bilgiler Tablo 1'de gösterildiği gibidir.

Tablo 1

Katılımcıların Özellikleri

\begin{tabular}{lclll}
\hline Kod & Görev Süresi (yıl) & Mezun Olunan Fakülte Türü & Öğrenim Durumu & $\begin{array}{l}\text { Program Komisyonlarına Katılma } \\
\text { Durumu }\end{array}$ \\
\hline $\begin{array}{llll}\text { Sinıf Öğretmenleri } \\
\text { SÖ1 }\end{array}$ & 21 & Mühendislik fakültesi & Lisans & Hayır \\
SÖ2 & 15 & Eğitim fakültesi & Lisans & Hayır \\
SÖ3 & 15 & Eğitim fakültesi & Lisans & Hayır \\
SÖ4 & 24 & Fen-edebiyat fakültesi & Lisans & Hayır \\
SÖ5 & 17 & Eğitim fakültesi & Lisans & Rapor hazırlama süreci \\
SÖ6 & 20 & Ziraat fakültesi & Lisans & Evet (2004) \\
SÖ7 & 12 & Eğitim fakültesi & Yüksek lisans & Tanıtım çalışmaları \\
SÖ8 & 12 & Eğitim fakültesi & Doktora & Hayır \\
SÖ9 & 13 & Eğitim fakültesi & Lisans & Hayır \\
SÖ10 & 31 & Öğretmen okulu & Ön lisans & Rapor hazırlama süreci \\
Okul Yöneticileri & & & Rapor hazırlama süreci \\
OY1 & 16 & Eğitim fakültesi & Lisans & Hayır \\
OY2 & 12 & Eğitim fakültesi & Lisans & Hayır \\
OY3 & 25 & İlahiyat fakültesi & Lisans & Hayır \\
OY4 & 15 & Eğitim fakültesi & Lisans & Hayır \\
OY5 & 13 & Eğitim fakültesi & Yüksek lisans & \\
\hline
\end{tabular}

Yukarıdaki tabloda da görüldüğü üzere, çalışmanın katılımcılarını eğitim fakültesi mezunu olmasının yanında, farklı fakültelerden mezun olmuş, ön lisans düzeyinden doktora düzeyine kadar eğitim seviyesine sahip ve program değiştirme komisyonlarının çeşitli aşamalarında görev almış yahut herhangi bir komisyonda yer almamış olmak üzere, farklı özelliklere sahip sınıf öğretmenleri ve okul yöneticileri oluşturmaktadır. Bu noktada araştırmacılar tarafından farklı özelliklere sahip bireylerden geniş bir açı yakalayıp, program güncellemelerine ilişkin ayrıntılı betimlemelere ulaşılması hedeflenmiştir. 


\section{Veri Toplama Aracı}

Çalışmanın verileri araştırmacılar tarafından hazırlanan yarı yapılandııılmış görüşmeler ile toplanmıştır. Görüşme sorularının hazırlanmasında öncelikle araştırmacılar tarafından alanyazın incelemesi gerçekleştirilmiştir. İncelemeler neticesinde sınıf öğretmenlerinin ve okul yöneticilerinin öğretim programlarının güncellenmesine ilişkin derinlemesine görüşlerini alabilmek amacıyla çok sayıda taslak görüşme sorusu hazırlanmıştır. Taslak sorular üzerinde tartışıldıktan sonra dil bilgisi alanında bir ve program geliştirme alanında doktora derecesine sahip iki akademisyene gönderilmiş ve uzman incelemesinden gelen dönütler doğrultusunda sorulara ilişkin uzlaşmaya varılmıştır. Hazırlanan görüşme sorularının işlerliği ve açıklı̆ıını belirleyebilmek adına iki sınıf öğretmeni ve bir okul yöneticisi ile pilot uygulamalar gerçekleştirilmiştir. Nihai görüş̧me formu "Sizce şu an uygulanan program ülkemizin ihtiyaçlarına cevap verebiliyor mu? Neden?", "Öğretim programlarını değiştirme kararı sizce hangi gerekçelerle verilmektedir? Eğitim paydaşlarının bu konuda fikirlerinin alındığını düşünüyor musunuz? Niçin?” gibi sorular içermektedir.

\section{Veri Toplama ve Analiz Süreçleri}

Araştırmada katılımcılarla yapılan yarı-yapılandırılmış görüşmeler, kendilerinin tercihlerine ve izin verme durumlarına göre ses kayıt cihazı ile veya araştırmacıların not almasıyla kaydedilmiş̧ir. Kayıt altına alınan bu veriler, araştırmacılar tarafından transkript edilmiştir.

Araştırmanın verileri, içerik analizine tabi tutulmuştur. İçerik analizinin kullanılmasıyla, benzer anlamlar bir araya getirilerek kodlar ve kategoriler oluşturulmuştur (Büyüköztürk ve diğ., 2010). Son olarak veriler, tablolar halinde sunulmuştur. Tablolar, sınıf öğretmenlerinin ve okul yöneticilerinin görüşlerinden örnek alıntılar yapılarak desteklenmiştir.

\section{Bulgular}

Sınıf öğretmenlerinin ve okul yöneticilerinin ilkokul programlarının güncellenmesine ilişkin görüşlerinin belirlenmesinin amaçlandığı bu çalışmada, sınıf öğretmenlerine ilişkin veriler beş tema altında ve her bir temaya ilişkin kategoriler oluşacak şekilde sunulmuştur. Okul yöneticilerinden elde edilen veriler ise dört tema ve ilgili temalara ilişsin kategoriler halinde sunulmuştur.

\section{Sınıf Öğretmenlerinin Görüşlerine İlişskin Bulgular}

Sınıf öğretmenlerinin ilkokul programlarının güncellenmesine ilişkin görüşleri; programların değiştirilme nedenleri, değiştirilen programların tanıtım sürecine ilişkin görüşleri, öğretim programlarının güncellenmesine yönelik önerileri, genel itibari ile değiştirilen öğretim programlarına ilişkin görüşler ve mevcut (2017) öğretim programına yönelik görüşler şeklinde olmak üzere beş tema altında toplanmıştır. Temalar ve temalara ilişkin kategoriler, öğretmenlerin kodları ve kategorilerin frekansları aşağıda tablo 2,3, 4, 5 ve 6 'da sunulmuştur.

\section{Sınıf Öğretmenlerinin Görüşlerine İlişskin Bulgular}

Tablo 2

Programların Değiştirilme Nedenlerine İlişkin Görüşler

\begin{tabular}{lll}
\hline Öğretmenlerin Görüşleri & Öğretmenlerin Kodları & $f$ \\
\hline Çağın ihtiyaçları & Ö1, Ö2, Ö3, Ö7, Ö9, Ö10 & 6 \\
Siyasi temelli / İdeolojik & Ö8, Ö9, Ö10 & 3 \\
Öğrencilere değer bilinci kazandırma & Ö4, Ö7, Ö10 & 3 \\
Belirli bir ölçüt yok & Ö1, Ö6 & 2 \\
Öğretmen, veli ve toplumun görüşleri & Ö2, Ö5 & 2 \\
\hline
\end{tabular}

Tablo 2'de görüldüğü üzere, katılımcı sınıf öğretmenleri öğretim programlarının değiştirilmesinde çağın ihtiyaçlarının $(f=\sigma)$ neden olduğuna sıklıkla değinmişlerdir. Bu kategoriye ilişkin Ö3 kod adlı katılımcı "içcinde bulunduğumuz çă̆ın ihtiyaçlarına göre yapılmaya çalışıldığını düşünüyorum. Çă̆a ayak uydurma ve yenilikleri yakalamak içi herhalde bu kadar sık değişiklik oluyordur." şeklinde görüş belirtmiştir. Ayrıca sınıf öğretmenleri öğretim programlarının siyasi temelli ve öğrencilere değer bilinci kazandırma gayesiyle değiştirilmesinin yanında $(f=3)$, herhangi bir nedeni olmadan yahut öğretmen, veli ve toplum paydaşları kaynaklı değişikliklerin olduğuna da $(f=2)$ değinmişlerdir. Ö9 kod adlı katılımcı, öğretim programlarının değiştirilmesinde siyasi temelli nedenlerin olduğuna değinirken; düşüncelerini "İdeolojik. Hükümetlerin genel oluşturmak istediği toplum yapısının eğitim programlarına yansıması olarak değerlendiriyorum.” şeklinde ifade etmiş̦tir. Bu görüş 
farklılıklarından yola çıkarak, programların güncellenme sebebine ilişkin öğretmenlere yeterince açıklama yapılmadığ

Tablo 3

Öğretim Programlarının Tanıtımlarına İlişskin Görüşler

\begin{tabular}{lll}
\hline Öğretmenlerin görüşleri & Öğretmenlerin Kodlar1 & $f$ \\
\hline Güncellenen programlar yeterince tanıtılmiyor. & Ö1, Ö2, Ö4, Ö5, Ö6, Ö8, Ö9, Ö10 & 8 \\
Genelgelerle öğreniyorum. & Ö1, Ö3, Ö5, Ö6, Ö9 & 5 \\
Medya, sendika arac1lı̆̆ıyla haberdar oluyorum. & Ö2, Ö4, Ö5, Ö8, Ö10 & 5 \\
İnternet & Ö6, Ö9 & 2 \\
Yeterince tanıtıldı̆̆ını düşünüyorum. & Ö3, Ö7 & 2 \\
\hline
\end{tabular}

Katılımcı sınıf öğretmenlerinin değiștirilen öğretim programlarından ne şekilde haberdar olduklarını, bu tanıtımların yeterli olup olmadığını betimlemek üzere yapılan görüşmelerde, öğretmenlerin büyük çoğunluğu güncellenen programlardan yeterince haberdar olmadıklarını $(f=7)$ belirtmişlerdir. Ö8 kod adlı öğretmen görüşlerini "Yeterince anlatılmıyor. Yani anlatılamıyor. Çünkü bilimsel temellerden uzaklaşan bir şeyi mantığa uygun anlatmak zordur. Değiştirenler bile zamanla hata yaptı̆̆ını anlıyor. " şeklinde belirtmiştir. Öğretmenlerin bir kısmı ise programların geliştirilme sürecinde değil de güncellemeler tamamlandıktan sonra genelgelerle ya da medya, sendika aracılığıyla haberdar olduklarını $(f=5)$ belirtmişlerdir. Öğretmenlerin bazıları internet aracılığı ile güncellemelerden haberdar olduklarını belirtirken; sadece iki ö ğretmen programların yeterince tanıtıldığını belirtmiştir. Bu öğretmenlerden Ö2 kodlu katılımc1 görüşlerini “Bence yeterince tanıtıllyor. Çünkü değişiklikler konusunda gerekli konferansların ve bilgilendirmelerin yapıldı ̆̆ kanaatindeyim.” şeklinde ifade etmiştir. Bu iki öğretmenden birinin, program tanıtım sürecinde görev almış olmasının sürecin yeterliliğine ilişkin görüşlerini etkilemiş olabilmesinden yola çıkarak; öğretmenlerin programların güncelleme, rapor hazırlama yahut tanıtım süreçlerinde daha aktif katılımının sağlanarak, öğretim programlarının tanıtılmasına yönelik eleştirilerin de bertaraf edilebileceği ve ortak bir konsensüs yaratılabileceği düşünülebilir.

Tablo 4

Öğretim Programlarının Gelişstirilmesine Yönelik Öneriler

\begin{tabular}{lll}
\hline Öğretmenlerin Görüşleri & Öğretmenlerin Kodlar1 & $f$ \\
\hline Genel bir çerçeve olmalı & Ö1, Ö2, Ö3, Ö4, Ö5, Ö7, Ö9 & 7 \\
Çağa uygun olmalı & Ö3, Ö4, Ö5, Ö6, Ö7, Ö8, Ö10 & 7 \\
Öğretmenler sürece daha çok dahil edilmeli & Ö2, Ö5, Ö6, Ö7, Ö10 & 5 \\
Siyasi bağlardan uzak tutulmalı & Ö8, Ö6, Ö9, Ö10 & 4 \\
Milli ve manevi değerler ön planda tutulmalı & Ö1, Ö7, Ö10 & 3 \\
Üretim odaklı programlar hazırlanmalı & Ö1, Ö7, Ö8 & 3 \\
Ayrıntılı (kazanım, yöntem, teknik vs.) program hazırlanmal1 & Ö6, Ö9 & 2 \\
\hline
\end{tabular}

Katılımcı sınıf öğretmenleri, öğretim programlarının geliştirilmesine yönelik öneriler kapsamında öğretim programlarının genel bir çerçeve halinde $(f=7)$ ve çağa uygun $(f=7)$ olması gerektiğine sıklıkla değinmişlerdir. Buna ilişkin Ö7 kod adlı katılımcı "Şimdi bunlar değişiyor, sonuçta ne değişiklik yapıldı söylenecek. Bu hani ögretmene anlatılacak ama tamamen ögretmenin de yaratıcılık tarafi var. Ona da birakılacak, tamamen robot gibi program yükle, gelsin bulsun değil. Zaten buna da ihtiyacı yok hiçbir öğretmenin bunun eğitimini almış zaten.” şeklinde görüşlerini ifade ederken, öğretim programlarının öğretmenlerin özgünlüğünü de katabileceği şekilde bir diğer deyişle genel bir çerçeve halinde hazırlanması gerektiğine değinmektedir. Aynı katılımcının görüşlerinde, çağa uygun şekilde güncellenen Fen Bilimleri dersi öğretim programının dünya ve evrene ilişkin konularla başlamasının, öğrencilerin derse yönelik ilgisini arttırdığı belirtilmektedir. Ayrıca Ö6, "Mevcut programla çalışmış ögretmen görüşleri son derece değerlidir. Programın eksik ya da hatalı bölümlerini en iyi ögrretmenler tespit edebilir." sözleriyle, öğretmenlerin sürece daha çok dahil edilmesinin önemini gözler önüne sermektedir. Kısacası ögretim programlarının öğretmenlerin daha fazla katılımıyla, uygulamada onlara esneklik tanıyacak ve çağın ihtiyaçlarına cevap verecek nitelikte hazırlanması gerektiği ifade edilebilir.

Tablo 5'te görüldüğü üzere katılımcı öğretmenlerin bazıları programların değişme sıklığının mevcut programın çıktılarının görülmeden yapılmasından kaynaklı gereksiz sıklıkta olduğuna değinirken; Ö10 kod adlı katılımcı görüşlerini "Biz mesela eski tip ögretmeniz. Planımızı programımızı yıllık her şeyimizi kendimiz yazarız. 
Nereden buluruz, yönetmelikten. Hiç planın yok gelmişsin okula, bence hiç önemli değil. Çünkü biliyorsun ne yapacă̆ını. Ama şu anda bilmiyorsun ne yapacă̆ını. Sen mi öğreneceksin, çocuğa mı öğreteceksin. İşte problem burada. Sürekli değişince ögrretmen de nasılsa yine değişir diye birinin yaptığını alıyor." ve Ö6 kod adlı katılımcı "Bir çocuk ancak üniversiteden mezun olduğunda, tabi tutulduğu sistemin başarılı olup olmadığını görebiliriz. Sistemin bütününü değiştirmek bir ihtiyaç değil, amaçlı bir çalışmadır diye düşünüyorum." ş̧eklinde ifade etmiştir. Katılımcılar, olumsuz yönünün olumlu yönünden fazlaya da olumlu yönünün olumsuz yönünden fazla olduğuna ilişkin görüşler de belirtmişlerdir. Ö4 kodlu katılımcı görüşleri "Burada öğretmene külfetten ziyade ögretmen bir programa alışıor, birkaç yıl devam ediliyor, değişiyor ve al baştan oluyor. Tabi burada illaki deneme, tecrübe edilme ve bizim görüşlerimiz doğrultusunda programlarl ele alma vardır. Yani olumlu yönleri olduğu gibi, olumsuz yönleri de var. Açıkçası benim açımdan olumlu yanları daha ă̆ır basıyor. Özellikle kazanım sayısının azaltılmasını ve işlenen bazı kazanımlarda değişikliğe gidilmesini olumlu buluyorum." İlgili tabloda görüldüğü üzere olumlu yönünün fazla olduğunu düşünen üç öğretmenden ikisinin programların güncellenmesinde rapor hazırlama ya da tanıtım çalışmalarında yer alan öğretmenler olmaları, programa ilişkin duyuşsal açıdan da daha yüksek motivasyona sahip olmalarına neden olabileceği ve bu durumun programların değişme sıklığına yönelik bakış açılarını etkilemiş olabileceği düşünülebilir.

Tablo 5

Programların Değişme Siklı̆̆ına İlişkin Görüşler

\begin{tabular}{llc}
\hline Öğretmenlerin Görüşleri & Öğretmenlerin Kodları & $f$ \\
\hline Sistemin çıktısı görülmeden gereksiz bir şekilde değişiyor. & Ö2, Ö3, Ö6, Ö8, Ö10 & 5 \\
Olumsuz yönü, olumludan fazla & Ö1, Ö6, Ö8, Ö9 & 4 \\
Olumlu yönü, olumsuzdan fazla & Ö4, Ö5, Ö7 & 3 \\
\hline
\end{tabular}

Tablo 6

2017 Öğretim Programına İlişkin Görüşler

\begin{tabular}{lll}
\hline Öğretmenlerin Görüşleri & Öğretmenlerin Kodları & $f$ \\
\hline Kazanımların sadeleştirilmesini olumlu buluyorum. & Ö1, Ö4, Ö5, Ö7, Ö8 & 5 \\
Kitaplar programla tam uyumlu olmalı & Ö2, Ö5, Ö7, Ö10 & 4 \\
Eski programların tekrarı niteliğinde & Ö3, Ö4, Ö5 & 3 \\
Okuma metinleri düzenlenmeli (Kısa, eğlenceli vb.) & Ö1, Ö6, Ö10 & 3 \\
Harf öğretimindeki grup/ses sırası netlik kazanmalı & Ö4, Ö6, Ö10 & 3 \\
Matematik kazanımları daha üst düzey olmalı & Ö6 & 1 \\
Dilbilgisi kazanımları dahil edilmeli & Ö6 & 1 \\
\hline
\end{tabular}

Tablo 6'da katılımcı öğretmenlerin 2017 yılında güncellenen öğretim programlarına ilişkin görüşleri yer almaktadır. Katılımcı sınıf öğretmenlerinden bazıları gerçekleştirilen görüşmelerde 2017 yılında güncellenen öğretim programlarında yapılan sadeleştirmeleri olumlu bir gelişme olarak görürken $(f=5)$, bazı öğretmenler özellikle ders kitaplarının programlarla uyumlu şekilde hazırlanması gerektiğine $(f=4)$ değinmişlerdir. Ö1 kodlu katılımcı görüşlerini “. Bariz bir değişiklik yok. Sadece tema ve ünitelerin ya da belirli kavramların adı değiştirilmiş. Bazı dersler kazanım sayısı azaltılmış ya da bazı kazanımlar birleştirilip, tek kazanım yapılmış. Bu durumun ise olumlu olduğunu düşünüyorum. Bu duruma ilişkin görüşlerimi de şubat ayında yapllan ankette belirttim." ve Ö5 kodlu katılımcı "Program tanıtımlarında öğrenci merkezliliğe, onların yaratıcılı̆̆ına vurgu yapılıyor fakat kitaplar gelince buna pek de uygun olmadı̆̆ın görüyoruz. O zaman söylenen ile yapılan bambaşka oluyor. Bize siz fikrinizi söylemeyin ögrenciye söyletin diyorlar ama bakınca programın ona göre hazırlanmadığını görüyorum. Anlatılanlar ile kitapta uygulananlar aynı olmuyor.” şeklinde ifade etmiştir.

\section{Okul Yöneticilerinin Görüşlerine İlişkin Bulgular}

Okul yöneticileri ile gerçekleştirilen görüşmelerin analizi neticesinde, ilkokullarda görev yapmakta olan yöneticilerin görüşlerinin programların güncellenmesinde dikkate alınan özellikler, programın güncelleme sürecine ilişkin eleştiriler, programların güncellenmesine ilişkin öneriler ve mevcut programa ilişsin görüşler şeklinde dört tema oluşturulmuştur. Temalar ve onlara ilişkin kategoriler, yöneticilerin kodları ve kategorilerin frekansları aşağıda tablo 7, 8, 9 ve 10'da sunulmuştur.

Okul yöneticilerinin öğretim programlarının güncellenme nedenlerine ilişkin görüşlerinde özellikle yetkililerin değişiklik kararı nedeniyle ilişsilendirecek şekilde görüş bildirdikleri $(f=3)$ belirlenmiştir. Y5 kod adlı okul 
yöneticisi bu kategoriye ilişkin görüşlerini “...bakanlı̆̆ın şeyi böyle yani diyorum ya, Talim ve Terbiye Kurulu Başkanlığl var, ne bileyim yani komisyonlarl var. Kitap yazan arkadaşlar var, akademisyenler var. Demek ki bunlar bir araya geliyor, değerlendiriyorlar..." şeklinde ifade etmiştir. Ayrıca çağa ayak uydurma, öğrencilere değer bilinci kazandırma, programların yoğun oluşu ve öğrencilerin ihtiyaçları kategorilerine ilişkin ikişer frekans $(f=2)$ ortaya çıkmıştır. Programların güncellenmesinin nedenleri olarak toplumun beklentileri, programların yetersiz bulunması ve öğretmenlerin taleplerinin dikkate alındığını belirten öğretmenler de verilerin analizi neticesinde ortaya çıkmıştır $(f=1)$. Eğitim paydaşlarının programların güncellenme gerekçesine yönelik görüşlerinin bu denli farklılaşmasında kendilerine ne sebeple değişiklik yapıldığına ilişkin yeterince açılama yapılmamasının etkili olduğu belirtilebilir.

Tablo 7

Programların Güncellenme Nedenlerine İlişkin Görüşleri

\begin{tabular}{lll}
\hline Yöneticilerin Görüşleri & Yönetici Kodları & $f$ \\
\hline Yetkililerin değişiklik kararı & Y2, Y4, Y5 & 3 \\
Çağa ayak uydurma isteği & Y1, Y3 & 2 \\
Öğrencilere değer bilinci kazandırma & Y4, Y5 & 2 \\
Programların yoğun oluşu & Y3, Y5 & 2 \\
Öğrencilerin ihtiyaçları & Y1, Y5 & 2 \\
Toplumun beklentileri & Y4 & 1 \\
Programların yetersiz bulunması & Y3 & 1 \\
Öğretmenlerin talepleri & Y1 & 1 \\
\hline
\end{tabular}

Tablo 8

Programların Güncellenme Sürecine Illişkin Eleştiriler

\begin{tabular}{lll}
\hline Yöneticilerin Eleştirileri & Yönetici Kodları & $f$ \\
\hline Programlar çok sık değiştiriliyor. & Y1, Y2, Y3, Y4, Y5 & 5 \\
Görüşlerimiz yeterince alınmıyor. & Y2, Y3, Y4 & 3 \\
Güncellemeler öncesi yeterince bilgi verilmiyor. & Y1, Y2, Y4 & 3 \\
Güncellenen programlar yeterince tanıtılmıyor. & Y1, Y2, Y4 & 3 \\
Okuma-yazma sisteminin yanlış olduğunu düşünüyorum. & Y2, Y4 & 2
\end{tabular}

Öğretim programlarının güncellenme sürecine ilişkin okul yöneticilerinin tamamı $(f=5)$ değişikliklerin çok sık gerçekleştirildiğine değinmişlerdir. Buna ilişkin en kapsamlı görüş Y5 kod adlı okul yöneticisinin “Ama ürün mesela, ürünü ortaya koyuyoruz, sonuçlar da çıktılarını da görmemiz lazım değil mi? Bu anlamda hani nasıl ifade edeyim. Yani çok acele etmemek lazım yani biraz diyorum ya zamana bırakmak lazım." sözlerinde ortaya çıkmaktadır. Okul yöneticilerinin görüşleri farklı kategoriler altında kategorize edilmiş olsa dahi katılımcıların öğretim programlarının güncellenme öncesinde, sırasında ya da sonrasında tanıtılmasında ve görüş alınmasında yetersizlikler olduğuna değinmelerinin yanında, okuma yazma sisteminin ilgili programda da sorunlar içerdiğine değinen okul yöneticileri $(f=2)$ olduğu da görülmektedir.

Tablo 9

Programların Güncellenmesine Yönelik Öneriler

\begin{tabular}{lll}
\hline Yöneticilerin Görüş̧eri & Yönetici kodları & $f$ \\
\hline Öğrencilerin seviyeleri dikkate alınmalı & Y1, Y2, Y3, Y5 & 4 \\
Milli ve manevi değerler ön planda tutulmalı & Y1, Y3, Y4 & 3 \\
Genel bir çerçeve şeklinde hazırlanmalı & Y1, Y4, Y5 & 3 \\
Öğretmenlerle birlikte hazırlanmalı & Y2, Y4 & 2 \\
Bütün detaylara yer verilmeli & Y2, Y3 & 2 \\
Toplumun ihtiyaçlarına yönelik olmalı & Y1 & 1 \\
Evrensel insan haklarını benimsemeli & Y3 & 1 \\
Sosyal ve kültürel faaliyetlere yer verilmeli & Y5 & 1 \\
Üretim odaklı olmalı & Y5 & 1 \\
\hline
\end{tabular}


Öğretim programlarının güncellenmesine yönelik önerilere ilişkin Tablo 9'a bakıldığında; okul yöneticilerinin program güncelleme aşamasında öğrenci seviyesine uygunluğun gözetilmesine $(f=4)$, milli ve manevi değerlerin ön planda tutulmasına $(f=3)$ ve genel bir çerçeve şeklinde sunulmasına $(f=3)$ sıklıkla değindikleri görülmektedir. Bu duruma ilişkin Y5 kod adlı okul yöneticisi öğrencilerin yaş seviyesinin dikkate alınması gerekliliğine değinirken "Öğrencilerin yaş seviyesi önemli öğrenciyi fazla yormayacak... Yormayacak derken, dinlendirecek etkinliklerle beraber ulaştıracak oyunlaştırmalarla gibi şeyler olabilir yani." sözlerine yer vermiştir. Ayrıca önerilerini "Evrensel insan haklarına, milli ve manevi değerlere bağlı kalmak şartıyla tüm gelişim ve ilerlemelerin dikkate alınması gerekir. Programlar, bu gelişimler üzerine kurulmalıdır. Ayrıca ögrencilerin hazırbulunuşluk düzeyleri ve kavrama kabiliyetlerini göz önünde bulundurulmalıdır." şeklinde ifade eden Y3 kod adlı katılımcının evrensel insan haklarına vurgu yapmasının dikkat çekici bir görüş olduğu düşünülebilir.

Tablo 10

2017 Öğretim Programına İlişkin Görüşler

\begin{tabular}{lll}
\hline Yöneticilerin Görüşleri & Yönetici Kodlar1 & $f$ \\
\hline Kazanım yoğunluğunda değişim & Y1, Y2, Y3, Y5 & 4 \\
Ülke ihtiyaçlarına kısmen cevap verecektir. & Y1, Y3 & 2 \\
Beklentilere cevap vermeyecektir. & Y2, Y4 & 2 \\
Değerler eğitimi ön planda & Y1, Y5 & 2 \\
Anlamaya yönelik faaliyetleri az & Y4 & 1 \\
\hline
\end{tabular}

Okul yöneticileri ile yapılan görüşmelerde 2017 öğretim programına ilişkin görüşleri 6 kategori altında değerlendirilebilecek şekilde analiz edilmiştir. Okul yöneticileri özellikle kazanım yoğunluğunda değişimler olduğuna $(f=4)$ ve ülke ihtiyaçlarına kısmen olsa da cevap vereceğine $(f=2)$ ve beklentileri karşılamayacağına $(f=2)$ değinmişlerdir. Bu duruma ilişkin en kapsamlı görüşü Y1 kodlu katılımcı "Bazı sinıf düzeylerinde kazanım sayıları artarken, bazılarında sadeleştiğini gördüm. Değerler eğitimine daha çok dikkat çekildiğini ve önem verildiğini gördüm. Bunun sonucunda artık okullarda "Değerler eğitimi" öğrenci kulübü de var. Bence ihtiyaçlara kismen cevap verecektir. Fakat bu programda zamanla ihtiyaçlara cevap vermeyebilir ve değişebilir." şeklinde ifade etmiştir. Y2 kodlu katılımc1 ise görüşlerini "En önemli iki değişiklik el yazlsı yerine düz yazı geldi ve harflerin verilişs sırası değişti. Sinıfların kazanım sayılarında artış ya da azalmalar var. Yeni program beklentilere tam olarak cevap vermeyecektir. Yine değişecektir. Çünkü bu programı öğretmenler hazırlamadl. Yerden bitme değil, tepeden inme bir program. Ayrıca biz program yapıcı değiliz, uygulayıcıyız. Hazırlanan programların hepsinin, öğretmenlerimizin üstün becerileri sayesinde uygulandığın düşünüyorum." şeklinde belirtmiştir. Okul yöneticilerinin yeni programa ilişkin görüşlerinin, uygulama sürecinde yer almamalarından dolayı daha genel ve tahmine dayalı olduğu ifade edilebilir.

\section{Sonuç ve Tartışma}

Araştırma sonucunda, sınıf öğretmenlerinin ve okul yöneticilerinin programların güncellenmesinde özellikle çağın ihtiyaçlarının ve onu yakalamanın etkili olduğunu düşündükleri belirlenmiştir. Nitekim yetkililer öğretim programlarını bu amaç doğrultusunda güncellemektedirler (Altun ve Şahin, 2009; Çubukçu, 2008; Ekiz, 2012; Gömleksiz, 2007; Kahramanoğlu, 2017; Pintó, 2005). Araştırmada bazı öğretmenlerin ise, öğretim programlarının yetkililerin ideolojik kararlarıyla değiştirildiğini düşündükleri görülmüştür. Bazı araştırmacılar (Ersoy, 2007; Kahramanoğlu, 2017; Şahin, 2009; Yüksel, 1998) da böyle düşünmektedirler ve bu merkeziyetçi anlayışı eleştirmektedirler. Ayrıca çalışmada çok az katılımcının öğretim programlarının öğretmenlerden gelen talepler doğrultusunda değiştirildiğini düşünmeleri dikkat çekicidir. Çünkü öğretim programlarının öğretmenlerden gelen istek üzerine geliştirilmeleri gerekir (Varış, 1996). Nihayetinde öğretim programlarının etkililiğine en iyi uygulayıcısı olan öğretmenler karar verebilir. Özetle sınıf öğretmenlerinin ve okul yöneticilerinin öğretim programlarının güncellenme nedenlerine ilişkin görüşleri farklılık göstermektedir. Bu duruma ise, yetkililerin programların değiştirilme nedenlerine ilişkin yeterince açıklama yapmamaları neden olabilir.

Araştırmada okul yöneticilerinin ve sınıf öğretmenlerinin büyük bir çoğunluğunun programların güncellenmesine ilişkin yeterince haberdar edilmediklerini, görüşlerinin alınmadığını ve tanıtım yapılmadığını düşündükleri tespit edilmiştir. Benzer şekilde Taşdemir ve diğerleri (2018) yaptıkları araştırmada yeni ilkokul öğretim programları hakkında öğretmenlerin bilgilendirilmelerinin yetersiz olduğunu ve hizmet içi eğitime gereksinim duyduklarını belirlemişlerdir. Oysaki 2017 öğretim programları öğretmenler, okul yöneticileri ve veliler gibi eğitim paydaşlarının internet üzerinden görüşleri alınarak geliştirilmiştir. Öğretmenlerin bu şekilde 
olumsuz görüş belirtmelerinde bu uygulamayı yeterli bulmamaları, görüşlerinin programlara aktarılmadığını düşünmeleri veya görüş bildirme sürecine nitelikli katılım göstermemeleri etkili olabilir. Ayrıca öğretmenlerin 2005 öğretim programının tanıtımına ilişkin görüşleri de aynı doğrultudadır. Öğretmenlere göre bu programa ilişkin kendilerine uygulamadan çok teoriye yönelik kısa süreli seminerler verilmiş ve yeterince tanıtım yapılmamıştır (Altun ve Şahin, 2009; Bukova Güzel ve Alkan, 2005; Güven, 2008; Hazır Bıkmaz, 2006; Karacaoğlu ve Acar, 2010). Bu durum öğretim programlarının başarıya ulaşmasını güçleştirebilir. Çünkü öğretmenlerin programlara ilişkin bilgi, inanç ve tutumları programların başarısında kritik öneme sahiptir (Gömleksiz, 2007; Tutkun ve Akosyalp, 2010; Yıldırım ve diğ., 2017).

Araştırma sonucunda hem sınıf öğretmenlerinin hem okul yöneticilerinin öğretim programlarının sıklıkla ve mevcut programın çıktılarının değerlendirilmeden güncellendiğini düşündükleri görülmüştür. Bu görüşe benzer şekilde Gelen ve Beyazıt (2007), öğretim programlarının yürürlükte kalmasının kısa süreli olduğunu belirtmişlerdir. Nitekim özellikle son birkaç yılda mevcut programlar kısa süreli olarak uygulanmakta ve yeterince değerlendirilmeden güncellenmektedirler. Bu bakımdan öğretmenlerin eleştirilerinde haklı oldukları söylenebilir. Çünkü mevcut programların daha uzun süreli uygulanmaları ve değerlendirilmeleri gerekir (Varış, 1996). Aksi takdirde bazı katılımcıların da belirttiği gibi program güncellemelerinin olumsuz etkileri olumlu etkilerinden çok daha fazla olabilmektedir.

Araştırmada, okul yöneticilerinin ve sınıf öğretmenlerinin öğretim programlarının öğrencilerin seviye farklılıklarına yönelik ve genel bir çerçeve șeklinde olmasını istedikleri belirlenmiștir. Collwill ve Carnel (2007) de programların bu şekilde olması ve öğretmenlere kendi yaklaşımlarını uygulamaya esneklik tanıması gerektiğini belirtmiş̧lerdir. Buna karşın bazı katılımcılar ise, öğretim programında bütün detaylara yer verilmesi gerektiğini ifade etmişlerdir. Öğretmenlerin bu konudaki görüş̧ ayrıllkları programlara yaklaşım, onu uygulama ve içeriğini zenginleştirebilme farklılıklarından kaynaklanabilir.

Araştırma sonucunda, sınıf öğretmenlerinin ve okul yöneticilerinin 2017 öğretim programını sade buldukları tespit edilmiştir. Nitekim Yıldırım ve diğerleri (2017), Türkçe Dersi Öğretim Programı kazanımlarının geçmişe nazaran azaldığını belirtmişlerdir. Bu sadeleşme yıllara göre karşılaştırma yapıldığında diğer derslerin öğretim programlarında da gözlemlenebilmektedir. Ayrıca araştırmada mevcut öğretim programının ülkenin ihtiyaçlarını ve beklentilerini karşılamaya ilişkin okul yöneticilerinin görüşlerinin farklılaştığı belirlenmiştir. Bu soruya cevap bulabilmek ve daha sağlıklı karar verebilmek için mevcut programla öğrenim görmeye başlayan öğrencilerin en azından ortaöğretimden mezun olmalarına kadar beklenmesi gerekir. Böylece mevcut öğretim programının etkililiği daha doğru bir şekilde değerlendirilebilecektir.

Araştırmanın bu sonuçları ve katılımcıların beklentileri doğrultusunda şu önerilerde bulunulabilir:

- Eğitimin paydaşlarına öğretim programlarının güncellenme nedenlerine ilişkin daha detaylı açıklamalar yapilmalidir.

- Program geliştirme sürecinin her aşamasında (öncesi, esnası ve sonrasında) eğitimin bütün paydaşlarının katılımı sağlanmalı ve görüşleri dikkate alınmalıdır.

- Öğretim programları, daha uzun süreli denenerek ve çıktıları değerlendirilerek güncellenmelidir.

- Öğretim programları, öğretmenlere görev yaptıkları çevrenin ve öğrencilerin özelliklerine göre esneklik sağlayabilecekleri genel bir çerçeve niteliğinde hazırlanabilir.

- Mevcut programa ilişkin farklı bölgelerde çalışan eğitim paydaşlarının görüşleri alınabilir ya da geniş katılımlı bir tarama çalışması yapılabilir. 


\section{Kaynakça/References}

Akınoğlu, O. (2005). Türkiye'de uygulanan ve değişen eğitim programlarının psikolojik temelleri. $M$. Ü. Atatürk Eğitim Fakültesi Eğitim Bilimleri Dergisi, 22, 31-46.

Akpınar, B. (2012). Eğitim programları ve öğretim. Ankara: Data Yayınları.

Altun, T. ve Şahin, M. (2009). Değişen ilköğretim programının sınıf öğretmenleri üzerindeki psikolojik etkilerinin incelenmesi üzerine nitel bir araştırma. Kastamonu Eğitim Dergisi, 17(1), 15-32.

Aydın, E. (2017). Türkçe dersi öğretim programlarının (2015 ve 2017) değerlendirilmesi. Turkish Studies, 12(28), 41-66. doi:10.7827/TurkishStudies. 12476

Baş, G. (2016). Sınıf öğretmenlerinin program geliştirme yeterliklerine ilişkin görüşlerinin bazı değişkenler açısından incelenmesi. Marmara Üniversitesi Atatürk Eğitim Fakültesi Dergisi, 43, 21-32. doi:10.15285/ebd.49293

Baxter, P. ve Jack, S. (2008). Qualitative case study methodology: Study design and implementation for novice researchers. The Qualitative Report, 13(4), 544-559.

Bukova Güzel, E. ve Alkan, H. (2005). Yeniden yapılandırılan ilköğretim programı pilot uygulamasının değerlendirilmesi. Kuram ve Uygulamada Ĕgitim Bilimleri, 5(2), 385-425.

Büyüköztürk Ş., Çakmak, E. K., Akgün Ö. E., Karadeniz, Ş. ve Demirel, F. (2010). Bilimsel araştırma yöntemleri (7. baskı). Ankara: Pegem Akademi.

Collwill, J. ve Gallagher, C. (2007). Developing a curriculum for the twenty-first century: The experiences of England and Northern Ireland. Prospects,37, 411-425.

Çubukçu, Z. (2008). Eğitim programı tasarımı ve geliştirilmesi. B. Duman (Yay. haz.). Öğretim ilke ve yöntemleri içinde (s. 131-175). Ankara: Maya Akademi.

Demirel, Ö. (2008). Öğretimi planlama ve değerlendirme: Öğretme sanatı. Ankara: Pegem Akademi.

Demirtaş, Z. (2017). Eğitimde program değerlendirme yaklaşımlarına genel bir bakış. Sakarya University Journal of Education, 7(4-özel say1), 756-768. doi:10.19126/suje.388616

Doll, R. C. (1996). Curriculum improvement: Decision making and process (9th edition). Boston, MA: Allyn\& Bacon.

Ekiz, D. (2012). Öğretimle ilgili temel kavramlar ve program geliştirme. S. Çepni ve S. Akyıldız (Yay. Haz.). Ögretim ilke ve yöntemleri içinde (s. 11-41). Trabzon: Celepler Matbaacılık.

Ekiz, D. (2015). Bilimsel araştırma yöntemleri (4. baskı). Ankara: Anı Yayıncılık.

Erden, M. (1998). Ĕgitimde program değerlendirme. Ankara: Anı Yayıncılık.

Ersoy, A. (2007). İlköğretim programının (1-5. sınıflar) uygulanmasına ilişkin aile görüşleri. Kuram ve Uygulamada Ĕgitim Bilimleri, 7(2), 727-763.

Gelen, İ. ve Beyazıt, N. (2007). Eski ve yeni ilköğretim programları ile ilgili çeşitli görüşlerin karşılaştırılması. Kuram ve Uygulamada Eğitim Yönetimi, 51, 457-476.

Gökçe, E. (1993). Ortaöğretim kurumlarındaki okul yöneticileri ve ögretmenlerin program geliştirme etkinliklerindeki görev ve davranışlarına ilişkin görüşlerinin belirlenmesi. (Yayınlanmamış yüksek lisans tezi). Ankara Üniversitesi, Ankara.

Gömleksiz, M. N. (2007). Yeni ilköğretim programına ilişkin öğretmen görüşlerinin çeşitli değişkenler açısından değerlendirilmesi. Eurasian Journal of Educational Research, 27, 69-82.

Güven, S. (2008). Sınıf öğretmenlerinin yeni ilköğretim ders programlarının uygulanmasına ilişkin görüşleri. Milli Eğitim Dergisi, 177, 224-236.

Hazır Bıkmaz, F. (2006). Yeni ilköğretim programları ve öğretmenler. Ankara Üniversitesi Eğitim Bilimleri Fakültesi Dergisi, 39(1), 99-116.

Johnson, B. ve Christensen, L. (2014). Eğitim Araştırmaları: Nicel, nitel ve karma yaklaşımlar (Çev. Demir, S. B.). Ankara: Eğiten Kitap. (Özgün çalışma, 2014)

Kahramanoğlu, R. (2017). Okul temelli program geliştirme. Disiplinlerarası Eğitim Araştırmaları Dergisi, 1(1), 29-36. 
Karacaoğlu, Ö. C. ve Acar, E. (2010). Yenilenen programların uygulanmasında öğretmenlerin karşılaşttğı sorunlar. Yüzüncü Yll Üniversitesi Eğitim Fakültesi Dergisi, 7(1), 45-58.

Karakuş, M. ve Mengi Us, F. (2014). İlköğretimde program değerlendirmenin öğretmen görüşleri doğrultusunda incelenmesi. Pegem Ĕgitim ve Öğretim Dergisi, 4(4), 1-22. doi:10.14527/140

Kürüm Yapıcıoğlu, D., Atik Kara, D. ve Sever, D. (2016). Türkiye'de program değerlendirme çalışmalarında eğilimler ve sorunlar: Alan uzmanlarının gözüyle. Uluslararası Eğitim Programları ve Öğretim Çalışmaları Dergisi, 6(12), 91-113.

Lau, D. C. (2001). Analysing the curriculum development process: Three models. Pedagogy, Culture and Society, 9(1), 29-44. doi:10.1080/14681360100200107

Oliva, P. F. ve Gordon, W. R. (2018). Program geliştirme (Çev. Korkmaz, İ.). Ankara: Pegem Akademi. (Özgün çalışma, 2012)

Oliva, P. F. (2009). Developing the curriculum (7th edition). Boston: Pearson.

Ornstein, A. C. \& Hunkins, F. P. (2013). Curriculum: Foundations, principles, an dissues (6th edition). Upper Saddle River, New Jersey: Merrill-Prentice Hall.

Özdemir, S. M. (2009). Eğitimde program değerlendirme ve Türkiye'de eğitim programlarını değerlendirme çalışmalarının incelenmesi. Yüzüncü Yll Üniversitesi Eğitim Fakültesi Dergisi, 6(2), 126-149.

Özpolat, A. R., Sezer, F., İşgör, İ. Y. ve Sezer, M. (2007). Sınıf öğretmenlerinin yeni ilköğretim programına ilişkin görüşlerinin incelenmesi. Milli Eğitim Dergisi, 174, 206-213.

Pintó, R. (2005). Introducing curriculum innovations in science: Identifying teachers' transformations and the design of related teacher education. Science Education, 89, 1-12. doi:10.1002/sce.20039

Stake, R. E. (1995). The art of case study research. ThousandOaks, CA: Sage.

Şahin, M. (2009). Cumhuriyet'in kuruluşundan günümüze Türkiye'de Hayat Bilgisi dersi programlarının gelişimi. Uluslararast Sosyal Araştırmalar Dergisi, 2(8), 402-410.

Şimşek, H. ve Yıldırım, A. (2011). Sosyal bilimlerde nitel araştırma yöntemleri. Ankara: Seçkin Yayıncılık.

Taşdemir, M., Şahin, C., Taşdemir, F., Kılıç, F., Dağıstan, A. ve Dağdelen, S. (2018). İlkokul İngilizce öğretim programlarına ilişkin öğretmen görüşleri. Eğitim ve Öğretim Araştırmaları Dergisi, 7(3), 121-130.

Tutkun, Ö. F. ve Aksoyalp, Y. (2010). 21. yüzyılda eğitimde program geliştirmede yönelim, kavram ve anlayışlar. Sakarya Üniversitesi Eğitim Fakültesi Dergisi, 19, 156-169.

Varış, F. (1996). Eğitimde program geliştirme. Ankara: Alkım Yayıncılık.

Wellington, J. (2000). Educational research, contemporary issues and practical approaches. London: Continuum.

Yapıcı, M. ve Demirdelen, C. (2007). İlköğretim 4. sınıf sosyal bilgiler öğretim programına ilişkin öğretmen görüşleri. Illköğretim Online, 6(2), 204-212.

Yar Yıldırım, V. (2018). Okul yöneticilerinin program okuryazarlıklarına yönelik bir hizmet içi eğitim programının gelişstirilmesi ve değerlendirilmesi. (Yayınlanmamış doktora tezi). Gaziosmanpaşa Üniversitesi, Tokat.

Yıldııı, K., Kandemir, E., Çınar, Z. ve Durak, M. (2017). Sınıf öğretmenlerinin Türkçe dersi öğretim programına yönelik görüşleri. Ana Dili Eğitimi Dergisi, 5(2), 135-154.

Yin, R. K. (1994). Case study research: Design and methods. Thousand Oaks, CA: Sage.

Yüksel, S. (1998). Program geliştirme sürecine öğretmen katılımı. Kuram ve Uygulamada Eğitim Yönetimi Dergisi, 4(1), 99-106. 